\title{
Emotional and Psychological Effects of Dysphagia: Validation of the Jugendwerk Dysphagia Emotion and Family Assessment (JDEFA)
}

\author{
Stefan Bushuven ${ }^{1,2,3} \cdot$ Isabell Niebel $^{1} \cdot$ Johanna Huber $^{3} \cdot$ Paul Diesener $^{1}$ \\ Received: 3 October 2020 / Accepted: 16 March 2021 / Published online: 4 April 2021 \\ (c) The Author(s), under exclusive licence to Springer Science+Business Media, LLC, part of Springer Nature 2021
}

\begin{abstract}
Introduction Patients suffering from swallowing disorders are experiencing emotional effects like anger, anxiety, and sadness. This may be affecting patient-therapist relation and family functioning. To assess emotional reaction and their influence on family systems, we developed a 55-item questionnaire based on the Atlas of Emotion and the Calgary Family Intervention Model.

Methods We recruited more than 160 participants to validate an online survey, namely the Jugendwerk Dysphagia Emotion and Family Assessment Score (JDEFA). Forty-Nine health care workers, patients, and family members completed the survey and provided additional comments regarding interactions of emotions and dysphagia. Analysis was accomplished by non-parametric tests and principal component analyses with Varimax rotation. Additionally, we accomplished a qualitative content analysis taking a phenomenological single-coder approach.

Results Analysis revealed a Cronbach's Alpha of 0.93. Using primary component analyses, justified by a Kaiser-MeyerOlkin value of 0.81 , we identified two main factors (emotion and family). Patients experienced sadness and anger more often than health care providers, whereas family members felt anxiety even more often. Our qualitative analysis revealed 20 themes ( 7 for anger, 2 enjoyment, 4 sadness, 3 anxiety, 2 disgust, 1 shame, and 1 punishment). Predominantly, the fear of choking was mentioned by patients, whereas professionals reported about the fear of making mistakes.

Conclusion The JDEFA is a valid and reliable testing tool for the assessment of swallowing disorders concerning emotional aspects and family functioning. Both factors have a significant role in dysphagia and evaluations should go along with functional assessments and psychological scores for a holistic understanding of swallowing disorders.
\end{abstract}

Keywords Dysphagia $\cdot$ Rehabilitation $\cdot$ Emotion $\cdot$ Questionnaire $\cdot$ Survey $\cdot$ Speech and language therapy

\section{Introduction}

In this study, we report on the validation and first results of the Jugendwerk Dysphagia Emotion and Family Assessment (JDEFA) for patients, family members, and health care providers. The aim of the study is to develop a reliable and

Stefan Bushuven

Stefan.bushuven@glkn.de

1 Department of Neurorehabilitation, Hegau-Jugendwerk Gailingen, Healthcare Association Constance (GLKN), Gailingen, Germany

2 Institute for Infection Control and Infection Prevention, Healthcare Association Constance (GLKN), Hegau-Bodensee-Hospital, 78315 Radolfzell, Germany

3 Institute for Medical Education, University Hospital, LMU Munich, Munich, Germany valid testing instrument to operationalize concerned persons' emotional and psychological reactions originating in swallowing disorders.

Test validation as a primary objective is necessary for further investigations about family interaction and emotional accuracy between patients, their family members, and caregivers. The secondary purpose of the JDEFA is getting a deeper insight on holistic and multidimensional aspects of dysphagia comprising objective and subjective criteria.

\section{Background}

Dysphagia is common in cerebro-vascular disease affecting $60 \%$ of all stroke patients accounting for 1.5 million victims per annum in Europe [1, 2]. It is occurring in presbyphagia striking more than one-third of all geriatric patients [3], in 
up to the half of all patients with throat and neck cancer after operation [4] radiation or chemotherapy [5], in noncancer surgery [6], in intensive care patients suffering from critical illness neuropathy [7] and children with aerodigestive disorders [8]. The economic burden is excessively high, e.g., resulting in additional cost of more than 6000 US $\$$ per hospital case in the United States [9].

Swallowing disorders are impairing social life [10] and are facilitating anxiety and depression [11]. Emotional and subjective impact of dysphagia have been described in qualitative investigations [12-14], have psychosocial effect on families $[15,16]$, and are impairing life quality $[17,18]$. Despite this and inclusion of some emotional aspects in recent scores [19], little has been published about a holistic assessment of emotions and family interactions.

Emotions are psychological and genetic "programs" for distinct behavior in response to our environment. Ekmans et al. described five basic emotions: anger, anxiety, disgust, enjoyment, and sadness, each with different categories depending on their intensity [20]. These emotions, which can be observed in animals as well [21], help us responding rapidly and therefore in predictable patterns to our environment, e.g., anxiety induces fight or flight reactions, disgust will lead to avoidance of food and influences mating [22], while sadness induces social responses of others, especially in family members. Emotions and affects should be set apart from "feelings" involving psychosocial experiences, e.g., love, honor, shame, proud, envy, jealousy or melancholy, and many more [23]. However, there is no consensus what an emotion exactly is, how it can be differentiated from other behavioral patterns, and how it exactly influences cognitive and physiological reactions [24].

Empathic accuracy is the ability to properly assess a person's emotions and feelings [25]. The term of empathic accuracy itself comprises different reactions to the other one's emotions and was reviewed by William Ickes referring to the German philosopher Max Scheler [26]: Compathy (empathic solidarity) is feeling the same as another person, e.g., if two siblings experience sadness about the neurological outcome of a loved person. Empathy is the competence to feel into another person by changing perspective. Mimpathy is emotional imitation. This is the competence to emulate a feeling or emotion comparable to professional acting. Sympathy is emotional participation and perception to a person's feelings. Transpathy is like an emotional contagion. It is being influenced and "infected" by the feelings of others. Last there is Unipathy, an emotional identification according to Ickes "in which one person is so absorbed by another person's feelings that there is a blurring of the distinction between self and other" [26].

Emotional reactions and mutual recognition of emotions are influencing the triangular relationship between health care providers, patients, and their family members-especially if a person's emotional reaction is misunderstood (e.g., resulting from communication barriers) or if it conflicts with one's another emotions or objectives [27-29].

An integrative model to assess family interaction is the Calgary Family Assessment and Intervention Model (CFAM/CFIM) [30]. In this model, the following aspects are operationalized to assess family interactions for therapists' interventions:

I. Structural: Family context (cultures, ethnics, social factors, religion, environment)

II. Structural: External (greater family, enhanced family systems)

III. Structural: Internal (family composition, sex, gender, rankings, subsystems)

IV. Functional: instrumental (daily activities)

V. Functional: expressive (communication, problemsolving, alliances, coalitions, roles, power)

VI. Developmental (states, objectives, interactions)

In context with dysphagia, these six elements can play a critical role, e.g., (I) impeding participation in religious and cultural efforts (e.g., eating altar bread), (II) social isolation from friends and relatives, (III) provoking conflicts within the family and between companions, (IV) minimizing visits to places of social life, like restaurants, $(\mathrm{V})$ interaction with communication and participation in family strategies especially when aphasia is present, and (VI) impairing future plans of all family members.

However, most of these aspects are influenced by the underlying disease, handicaps, and other comorbidities and therefore are not limited to dysphagia alone. Furthermore, there are intercorrelations of the items, with the possibility of a loss of distinction between emotions (e.g., when sadness, fear and anger interact, resulting in an indefinite "emotional storm"). On the other hand, for medical professionals and persons in education profound understanding of these psycho-emotional and family "side effect" is crucial to maintain a sufficient therapist-patient interaction influencing the short- and long-term outcome.

\section{Objective}

The aim of this study was to design and test a novel assessment instrument intended to operationalize emotional and family psychological effects of dysphagia. This was done using established psychological operationalization models. To do so, we took an approach comprising expert panel discussions groups, face validity verification by specialists, iterative modifications of questionnaire items, and finally an 
online-based evaluation in the three groups: Patients, family members, and health care professionals.

It was intended for future investigations concerning the multidimensional impact of dysphagia on patients, family members, and therapists and assessments of empathic accuracy.

For our instrument, we hypothesized satisfactory reliability (Cronbach's Alpha at least 0.6 ) and construct validity (factor analysis) concerning health care providers, patients capable to use the test, and family members. In this first step, we did not concentrate on subgroup or triplet interaction or empathic accuracy.

In this study, we provide readers with JDEFA testing results and additional qualitative data about emotions and family factors in the context of dysphagia.

\section{Materials and Methods}

\section{Study Design}

We conducted an international anonymous cross-sectional study using an interprofessional designed online questionnaire in German language with 39 primary (5-point Likert scale) and 9 demographic items and 8 items with optional free text entries (see Table 1).

\section{Setting}

The authors (physicians, psychologists, respiratory therapists) and a facilitated discussion group consisting of speech and language therapists developed the questionnaire taking an approach with exchange of different versions between an expert panel and the discussion group:

The first step included multiple facilitated discussion groups consisting of the two physicians and one specialized nurse considering the Ekman approach and individual experience. This experience is comprising 25 years of medical expertise in aerodigestive therapy and dysphagiology on the side of the senior physician, more than ten years for the nurse working as an assistant in dysphagiology, pediatric critical care, and respiration therapy and on the side of the second physician more than ten years expertise in critical care, anesthesiology, and emergency medicine.

After the iterative discussion, we developed a first version consisting of four questions per emotion and Calgary item. The working-group checked the developed instrument for face validity and edited the questions multiple times. Next, we asked an expert panel consisting of 15 medical experts and questionnaire development specialists for external validation and quality assessment. This led to a reduction of items and some specifications to enhance questionnaire applicability. Next, we presented the questionnaire to more than 30 speech and language therapists from Germany and Switzerland to assure face and content validity. This facilitated discussion group validation was held during the Annual Meeting of the Dysphagia Network South West Germany 2019 at Helios Hospital Uberlingen, Lake of Constance. Under consideration of this additional input, further item reduction was accomplished. After finalization of the questionnaire 25 nurses, physicians and speech and language therapists at Hegau-Jugendwerk-Gailingen and Hegau-Bodensee Hospital Singen pre-tested it from October 2019 to January 2020. After these first satisfying pre-tests concerning validity and reliability, the questionnaire was distributed online from February to June 2020. Considering the SARS-CoV-2 pandemic, we decided to provide the survey online only.

We distributed the questionnaire multiple times in different German-speaking online boards, online communities, self-help organizations, and social networks (e.g., Facebook, Xing, Inlinked) accessed by patients, relatives, speech and language therapists, patho-linguists, home intensive care givers, and palliative care health care workers from Germany, Austria, and Switzerland.

Distribution of the anonymous questionnaire was done using umfrageonline.com by the Swiss provider Enuvo $\mathrm{GmBH}$, Zurich. Anonymity was guaranteed by blinding IP addresses towards the investigators by Enuvo and the waiver to ask for an identification in the survey.

\section{Participants}

Recipients were persons with dysphagia or caregivers for persons with dysphagia. This included professional health care providers, lay persons, or professionalized family members. There was no further selection of participants and no control for multiple access to the survey or for barriers to conduct the survey (e.g., for participants with motoric handicap or aphasia). Exclusion criteria were a decline to participate or preterm cancelation of the survey.

\section{Variables}

Variables and survey items are shown in Table 1. Items 1 to 9 display demographic data (objective and subjective age, gender, relation to dysphagia) for subgroup definition, especially for validation in the intended groups "patients" (PAT), "family members" (FAM), and "health care providers" (HCP). Additionally, we collected further data concerning the severity of dysphagia and coincident conditions like tracheotomy and tube feeding. In items 5 and 6, we asked for the most severe complications respondents experienced and their incidence.

Items 10 to 30 focused on emotions and feelings accompanying dysphagia. With respect to the decay of methods 
Table 1 English translation of the questionnaire

\begin{tabular}{ll}
\hline No Question Answers & An \\
\hline
\end{tabular}

1 [Group]

To what extend are you affected by dysphagia?

In welcher Form sind Sie von Dysphagie betroffen?

2 [Airway]

What is the airway condition in your case or in the case of a person with dysphagia you care for?

Welcher Zustand liegt bei Ihnen als Betroffene(r) oder der betreuten Person mit Dysphagie vor?

3 [Gastrointestinal]

What is the gastro-intestinal condition in your case or in the case of a person with dysphagia you care for?

Welcher Zustand liegt bei Ihnen als Betroffene(r) oder der betreuten Person mit Dysphagie vor?

\section{4 [Cause]}

What is the cause for the dysphagia you are experiencing?

Wodurch ist die Dysphagie, die sie erleben, bedingt?
I am suffering from dysphagia

(Ich leide an einer Schluckstörung)

I am a relative of a person suffering from dysphagia (Ich bin Angehöriger einer Person mit Schluck-

störung)

I am a health care provider

(Ich bin eine medizinische Fachkraft)

I am a relative and a health care provider

(Ich bin Angehörige(r) und medizinische Fachkraft)

No Answer

(Keine Antwort)

Free text entry

(Freitext-Eintragung)

No answer possible

(Keine Antwort möglich)

No tracheostomy

(Kein Luftröhrenschnitt)

Tracheostomy, never blocked

(Tracheostomie, nie geblockt)

Tracheostomy, $<12 \mathrm{~h}$ per day blocked

(Tracheostomie, $<12 /$ pro Tag geblockt)

Tracheostomy, $>12 \mathrm{~h}$ per day blocked

(Tracheostomie, $>12 /$ pro Tag geblockt)

Tracheostomy, all day blocked

(Tracheostomie, immer geblockt)

I am a health care provider caring for patients with multiple conditions

(Ich betreue als Fachkraft mehrere Personen mit unterschiedlichen Atemwegshilfen)

\section{No answer}

(Keine Antwort möglich)

No devices

(Keine Hilfsmittel wie PEG oder Magensonde PEG)

PEG and additional eating per os

(PEG komplette Ernährung, Essen und Trinken zum Wohlbefinden)

PEG without eating

(PEG, komplette Ernährung, kein Essen oder

Trinken)

Caring for patient with different conditions

(Ich betreue als Fachkraft mehrere Personen mit unterschiedlichen Ernährungshilfsmitteln)

No answer

(Keine Antwort möglich)

ENT-operation or radiation therapy

(Bedingt durch eine HNO-Operation oder Strahlentherapie)

Traumatic

(Bedingt durch einen Unfall)

Nerval disease like Stroke or ALS

(Bedingt durch eine Nervenerkrankung (z.B. Schlaganfall, ALS))

Caring for patient with different conditions

(Ich betreue als Fachkraft mehrere Personen mit unterschiedlichen Gründen für eine Dysphagie) 
Table 1 (continued)

\begin{tabular}{|c|c|c|}
\hline No & Question & Answers \\
\hline $\begin{array}{l}5 \\
\text { a-e }\end{array}$ & $\begin{array}{l}\text { [Severity of events] } \\
\text { What is the severest complication of dysphagia you can remember? } \\
\text { coughing incidents? } \\
\text { Asphyxia / Cyanosis } \\
\text { Pneumonia } \\
\text { Unintended loss of weight } \\
\text { Dehydration } \\
\text { Wie stark war die stärkste der folgenden Komplikationen der Schluckstörung an die } \\
\text { Sie sich erinnern können? } \\
\text { Hustenanfälle } \\
\text { Erstickungsanfälle/Blau werden } \\
\text { Lungenentzündung } \\
\text { Ungewollte Gewichtsabnahme } \\
\text { Erheblicher Flüssigkeitsmangel }\end{array}$ & $\begin{array}{l}\text { Never experienced } \\
\text { (nie erlebt) } \\
\text { Sustained without medical help } \\
\text { (ohne med. Hilfe überwunden) } \\
\text { Sustained with medical help } \\
\text { (mit med. Hilfe überwunden) } \\
\text { Emergency medical service needed } \\
\text { (Rettungsdienst notwendig) } \\
\text { Hospital admission needed } \\
\text { (Aufnahme im Krankenhaus benötigt) } \\
\text { Intensive care needed } \\
\text { (Intensivstation benötigt) } \\
\text { No rating possible } \\
\text { (nicht beurteilbar) }\end{array}$ \\
\hline 6 & $\begin{array}{l}\text { [Occurrence of events] } \\
\text { How often do these incidents occur? } \\
\text { coughing incidents? } \\
\text { Asphyxia / Cyanosis } \\
\text { Pneumonia } \\
\text { Unintended loss of weight } \\
\text { Dehydration } \\
\text { Wie häufig treten diese stärksten Ereignisse ein? } \\
\text { Hustenanfälle } \\
\text { Erstickungsanfälle/Blau werden } \\
\text { Lungenentzündung } \\
\text { Ungewollte Gewichtsabnahme } \\
\text { Erheblicher Flüssigkeitsmangel }\end{array}$ & $\begin{array}{l}\text { Never experienced } \\
\text { (nie erlebt) } \\
\text { Single event } \\
\text { (einmalig) } \\
\text { Less than once per } 3 \text { years } \\
\text { (weniger als einmal in } 3 \text { Jahren) } \\
\text { Less than once per year } \\
\text { (weniger als einmal pro Jahr) } \\
\text { Less than once per } 3 \text { months } \\
\text { (weniger als einmal pro } 3 \text { Monate) } \\
\text { Less than once per month } \\
\text { (weniger als einmal pro Monat) } \\
\text { More frequent or permanent } \\
\text { (häufiger oder Dauerzustand) }\end{array}$ \\
\hline 7 & $\begin{array}{l}\text { [Age objective] } \\
\text { How old are you? } \\
\text { Wie alt sind Sie? }\end{array}$ & Numeric \\
\hline 8 & $\begin{array}{l}\text { [Age subjective] } \\
\text { How old do you feel? } \\
\text { Wie alt fühlen Sie sich? }\end{array}$ & Numeric \\
\hline 9 & $\begin{array}{l}\text { [Gender] } \\
\text { What is your gender? } \\
\text { Welches Geschlecht haben Sie? }\end{array}$ & Male, female divers, other \\
\hline 10 & $\begin{array}{l}\text { [Anger 1] } \\
\text { If I think about eating impaired by dysphagia, I get angry } \\
\text { Wenn ich an das Thema Essen mit Schluckstörung denke werde ich wütend }\end{array}$ & 5-point Likert scale \\
\hline 11 & $\begin{array}{l}\text { [Joy 1] } \\
\text { If I think about eating impaired by dysphagia, I am happy } \\
\text { Wenn ich an das Thema Essen mit Schluckstörung denke freue ich mich }\end{array}$ & 5-point Likert scale \\
\hline 12 & $\begin{array}{l}\text { [Sadness 1] } \\
\text { If I think about eating impaired by dysphagia, I feel sad } \\
\text { Wenn ich an das Thema Essen mit Schluckstörung denke werde ich traurig }\end{array}$ & 5-point Likert scale \\
\hline 13 & $\begin{array}{l}\text { [Disgust 1] } \\
\text { If I think about eating impaired by dysphagia, I am disgusted } \\
\text { Wenn ich an das Thema Essen mit Schluckstörung denke beginne ich mich zu ekeln }\end{array}$ & 5-point Likert scale \\
\hline 14 & $\begin{array}{l}\text { [Anxiety 1] } \\
\text { If I think about eating impaired by dysphagia, I feel anxious } \\
\text { Wenn ich an das Thema Essen mit Schluckstörung denke sorge ich mich }\end{array}$ & 5-point Likert scale \\
\hline 15 & $\begin{array}{l}\text { [Punishment 1] } \\
\text { If I think about eating impaired by dysphagia, I feel to be punished } \\
\text { Wenn ich an das Thema Essen mit Schluckstörung denke fühle ich mich gestraft }\end{array}$ & 5-point Likert scale \\
\hline 16 & $\begin{array}{l}\text { [Shame 1] } \\
\text { If I think about eating impaired by dysphagia, I am ashamed } \\
\text { Wenn ich an das Thema Essen mit Schluckstörung denke schäme ich mich }\end{array}$ & 5-point Likert scale \\
\hline
\end{tabular}


Table 1 (continued)

\begin{tabular}{ll}
\hline No & Question \\
\hline 17 & [Anger 2] \\
To be impaired for eating on the natural way provokes wrath \\
Nicht ungehindert oder nicht auf natürlichem Wege essen zu können erzeugt in mir \\
Zorn
\end{tabular}

18 [Joy 2]

To be impaired for eating on the natural way provokes satisfaction

Nicht ungehindert oder nicht auf natürlichem Wege essen zu können erzeugt in mir Zufriedenheit

19 [Sadness 2]

To be impaired for eating on the natural way provokes grief

Nicht ungehindert oder nicht auf natürlichem Wege essen zu können erzeugt in mir Kummer

20 [Disgust 2]

To be impaired for eating on the natural way is repulsing

Nicht ungehindert oder nicht auf natürlichem Wege essen zu können erzeugt in mir Widerwille

21 [Anxiety 2]

To be impaired for eating on the natural way is fearsome

Answers

5-point Likert scale

Nicht ungehindert oder nicht auf natürlichem Wege essen zu können erzeugt in mir Angst

22 [punishment 2]

To be impaired for eating on the natural way feels like a penalty

Nicht ungehindert oder nicht auf natürlichem Wege essen zu können erzeugt in mir Bestrafungsempfinden

23 [shame 3]

To be impaired for eating on the natural way is embarrassing

Nicht ungehindert oder nicht auf natürlichem Wege essen zu können erzeugt in mir Verlegenheit

24 [Anger 3]

To be physically impeded to eat or drink is making me mad about it

Ein körperlich eingeschränktes Vermögen zu Essen und Trinken macht mich sauer

25 [Joy 3]

To be physically impeded to eat or drink is delightful

Ein körperlich eingeschränktes Vermögen zu Essen und Trinken macht mich glücklich

26 [Sadness 3]

To be physically impeded to eat or drink is desperate

Ein körperlich eingeschränktes Vermögen zu Essen und Trinken lässt mich verzweifeln

27 [Disgust 3]

To be physically impeded to eat or drink is nauseating

Ein körperlich eingeschränktes Vermögen zu Essen und Trinken ekelt mich

28 [Anxiety 3]

To be physically impeded to eat or drink is frightening

Ein körperlich eingeschränktes Vermögen zu Essen und Trinken erzeugt in mir Furcht

29 [Punishment 3]

To be physically impeded to eat or drink is a torture

Ein körperlich eingeschränktes Vermögen zu Essen und Trinken ist für mich eine Folter

30 [Punishment 3]

To be physically impeded to eat or drink is awkward

Ein körperlich eingeschränktes Vermögen zu Essen und Trinken ist peinlich

31 [Anger 4 free text]

How do you experience anger in association with dysphagia?

5-point Likert scale

5-point Likert scale

5-point Likert scale

5-point Likert scale

5-point Likert scale

5-point Likert scale

5-point Likert scale

5-point Likert scale

5-point Likert scale

5-point Likert scale

5-point Likert scale

5-point Likert scale

5-point Likert scale

Free text entry without limit 
Table 1 (continued)

No Question Answers

32 [enjoyment 4 free text]

How do you experience happiness in association with dysphagia?

Free text entry without limit

Wie erleben Sie "Freude" im Zusammenhang mit Schluckstörungen?

33 [sadness 4 free text]

How do you experience sadness in association with dysphagia?

Wie erleben Sie "Traurigkeit" im Zusammenhang mit Schluckstörungen?

34 [Anxiety 4 free text]

How do you experience anxiety in association with dysphagia?

Wie erleben Sie "Angst" im Zusammenhang mit Schluckstörungen?

35 [Disgust 4 free text]

How do you experience disgust in association with dysphagia?

Wie erleben Sie "Ekel" im Zusammenhang mit Schluckstörungen?

36 [Disgust 4 free text]

How do you experience the feeling to be punished in association with dysphagia?

Wie erleben Sie "Strafe “ im Zusammenhang mit Schluckstörungen?

37 [Shame 4 free text]

How do you experience shame in association with dysphagia?

Wie erleben Sie "Scham “ im Zusammenhang mit Schluckstörungen?

38 [Context 1]

The proficiency to eat and drink influences the origin of the family

Die Fähigkeit zu Essen und Trinken beeinflusst die Herkunft der Familie

39 [External 1]

The proficiency to eat and drink influences contacts to family member's friends

Die Fähigkeit zu Essen und Trinken beeinflusst den Kontakt zu Freunden der

Familie

40 [Internal 1]

The proficiency to eat and drink influences family members' relation

Die Fähigkeit zu Essen und Trinken beeinflusst das Verhältnis der Familienmitglieder zueinander

41 [Instrumental 1]

The proficiency to eat and drink influences all-day activities

Die Fähigkeit zu Essen und Trinken beeinflusst alltägliche Aktivitäten der Familie

42 [Expression 1]

The proficiency to eat and drink influences family members' values

Die Fähigkeit zu Essen und Trinken beeinflusst die Wertvorstellungen von Familienmitgliedern

43 [Development 1]

The proficiency to eat and drink influences the family development

Die Fähigkeit zu Essen und Trinken beeinflusst die Zukunft der Familie

44 [Context 2]

Communal Meals have a long tradition

Mahlzeiten einnehmen zu können haben eine lange familiäre Tradition

45 [External 2]

Communal Meals are important for social contacts to relatives

Mahlzeiten einnehmen zu können sind wichtig für soziale Kontakte zu Verwandten

46 [Internal 2]

Communal Meals are important for family cohesion

Mahlzeiten einnehmen zu können fördern den Familienzusammenhalt

47 [Instrumental 2]

Communal Meals are part of daily life

Mahlzeiten einnehmen zu können gehören zum täglichen Leben

48 [expressional 2]

Communal Meals are important for family interaction

Mahlzeiten einnehmen zu können sind wichtig für den Austausch in der Familie

49 [developmental 2]

Communal Meals are helpful to create plans for the family

Mahlzeiten einnehmen zu können helfen der Familie Pläne und Ziele zu bestimmen

Free text entry without limit

Free text entry without limit

Free text entry without limit

Free text entry without limit

Free text entry without limit

5-point Likert scale

5-point Likert scale

5-point Likert scale

5-point Likert scale

5-point Likert scale

5-point Likert scale

5-point Likert scale

5-point Likert scale

5-point Likert scale

5-point Likert scale

5-point Likert scale

5-point Likert scale 
Table 1 (continued)

\begin{tabular}{|c|c|c|}
\hline No & Question & Answers \\
\hline 50 & $\begin{array}{l}\text { [Context 3] } \\
\text { Eating and drinking have an effect on cultural, spiritual and religious backgrounds } \\
\text { of families } \\
\text { Essen und Trinken wirkt sich aus auf den kulturellen, spirituellen und religiösen } \\
\text { Hintergrund der Familie }\end{array}$ & 5-point Likert scale \\
\hline 51 & $\begin{array}{l}\text { [External 3] } \\
\text { Eating and drinking have an effect on the connection to relatives and friends } \\
\text { Essen und Trinken wirkt sich aus auf das Verhältnis zu Verwandten und Bekannten }\end{array}$ & 5-point Likert scale \\
\hline 52 & $\begin{array}{l}\text { [Internal 3] } \\
\text { Eating and drinking have an effect on family interactions } \\
\text { Essen und Trinken wirkt sich aus auf das familiäre Miteinander }\end{array}$ & 5-point Likert scale \\
\hline 53 & $\begin{array}{l}\text { [Instrumental 3] } \\
\text { Eating and drinking have an effect on the day-to-day-life } \\
\text { Essen und Trinken wirkt sich aus auf den Alltag der Familie }\end{array}$ & 5-point Likert scale \\
\hline 54 & $\begin{array}{l}\text { [Expressional 3] } \\
\text { Eating and drinking have an effect on problem-solving activities in the family } \\
\text { Essen und Trinken wirkt sich aus auf die Fähigkeiten der Familie, Problem zu } \\
\text { überwinden }\end{array}$ & 5-point Likert scale \\
\hline 55 & $\begin{array}{l}\text { [Developmental 3] } \\
\text { Eating and drinking have an effect on objectives of families for the future } \\
\text { Essen und Trinken wirkt sich aus auf die Pläne der Familie für die Zukunft }\end{array}$ & 5-point Likert scale \\
\hline 56 & $\begin{array}{l}\text { [Free text] } \\
\text { Do you have any comments or suggestions? } \\
\text { Haben Sie Anmerkungen? } \\
\text { Hier ist ein freies Feld für Kommentare! }\end{array}$ & Free text entry without limitation \\
\hline
\end{tabular}

bias (e.g., lowering the attentiveness of respondents due to signs of response fatigue and therefore biasing answers), each emotion was presented three times (and not four times as initially planned) in different wordings to get triangulation, to limit errors, and to ensure construct validity. Possible answers were complete (1), mainly (2), partial (3), minor (4), and no agreement (5) to the presented emotional states. A sixth answer "no answer possible" (0) was introduced to increase content validity and for ethical reasons. To test construct validity and reliability, all six answers were analyzed. For further results, the "no answer possible" responses were excluded for statistical preservation of ordinal scaling and test validity. This was repeated for items 39 to 55 concerning the six aspects of the family intervention model using the same Likert scale. Items 31 to 38 and 56 were free text entries to enable hypotheses development.

Item composition and wording were derived deductively from the Atlas of Emotions and the CFAM/CFIM. The items were presented to 35 speech and language therapists from the association "Dysphagia Network Southwest Germany" (Dysphagie Netzwerk Suedwest e.V.) for content validation. These group stated that "shame" and the "feeling to be punished" occur repeatedly. Thus, we included them before testing for construct validity and reliability showing satisfactory results (Cronbach's Alpha 0.93) for the prototype version.
After this last step, we successfully consulted the ethical board of the physician association Baden Wuerttemberg in Stuttgart (Ethikkommission der Landesaerztekammer Baden-Wuerttemberg) for ethical permission to conduct the study.

\section{Bias}

Selection bias as well as decay of methods (that is the effect of exhaustion for questions presented later in the survey) and the tendency to the center (the tendency to answer with a "neutral" option) were the main bias to be addressed in this study.

We tried to limit the selection bias by a broad and multiple dissemination of the survey. Nevertheless, we could not reach persons with no access to the internet or persons suffering from dysphagia with severe communication barriers like aphasia or cognitive impairment or psycho-motor handicaps.

To prevent the decay of methods, especially under concerns for patients who may be sooner exhausted due to physically handicap, we reduced our items from initial four times asking about one aspect to three times.

In the very first version, we used a 5-point Likert scale with a positive/negative agreement and a neutral answer. To reduce the error of the tendency to the center (with the 
tendency that real neutral answers would invalidly to content comprise the "no answer possible"), we changed to a Likert scale with the option to omit an answer.

\section{Study Size}

We conducted the study with a goal of at least 80 participants completing the survey.

\section{Statistical Methods}

We conducted the statistics with use of Microsoft Excel (Microsoft, Seattle, USA) and XLSTATS (Addinsoft, New York, USA). Statistical methods for psychometric instruments comprised separate tests for construct validity (primary component analysis with Varimax Rotation to assess dimensionality and item composition) and reliability (Cronbach's Alpha) for the emotion items (items 10-30) and the family items (items 39-55).

Additional analysis was conducted using non-parametric tests corrected for multiple testing (Kruskal-Wallis tests) and correlation analyses (Kendall's $\tau$ ) for parameter analysis and comparison of PAT, FAM, and HCP groups.

\section{Qualitative variables}

Qualitative variables were evaluated using the singleresearcher phenomenological (that means no interaction of examiners and respondents) approach reported by Bradley [31]. Free text entries were simplified (decontextualization), condensed to recurring codes (coding) and these codes summarized and recontextualized to form the main themes. Analysis was conducted by the primary author of this paper with experience in critical care, emergency medicine, medical didactics, and infection prevention.

Table 2 Descriptive data of all participants and the three subgroups

\begin{tabular}{|c|c|c|c|c|c|c|c|c|c|c|c|}
\hline \multirow{2}{*}{$\begin{array}{l}\text { Group } \\
\text { Group (n) }\end{array}$} & \multicolumn{2}{|l|}{ All } & \multicolumn{2}{|l|}{ Patients } & \multicolumn{4}{|c|}{$\begin{array}{l}\text { Family } \\
\text { Members }\end{array}$} & \multicolumn{3}{|c|}{ Health Care Provider } \\
\hline & 94 & & 21 & & 17 & & & & 56 & & \\
\hline Group (\%) & $100 \%$ & & $22,3 \%$ & & $18,1 \%$ & & & & $59,6 \%$ & & \\
\hline Airway & $\mathrm{n}$ & $\%$ & $\mathrm{n}$ & $\%$ & $\mathrm{n}$ & $\%$ & & & $\mathrm{n}$ & $\%$ & \\
\hline -No answer & 8 & $8,51 \%$ & 1 & $4,76 \%$ & 4 & $23,53 \%$ & & & 3 & $5,36 \%$ & \\
\hline -No tracheostomy & 32 & $34,04 \%$ & 16 & $76,19 \%$ & 9 & $52,94 \%$ & & & 7 & $12,50 \%$ & \\
\hline -Never blocked & 5 & $5,32 \%$ & 3 & $14,29 \%$ & 2 & $11,76 \%$ & & & 0 & $0,00 \%$ & \\
\hline -Blocked $<12 \mathrm{~h} / \mathrm{d}$ & 0 & $0,00 \%$ & 0 & $0,00 \%$ & 0 & $0,00 \%$ & & & 0 & $0,00 \%$ & \\
\hline -Blocked > $12 \mathrm{~h} / \mathrm{d}$ & 0 & $0,00 \%$ & 0 & $0,00 \%$ & 0 & $0,00 \%$ & & & 0 & $0,00 \%$ & \\
\hline -Ever blocked & 2 & $2,13 \%$ & 1 & $4,76 \%$ & 0 & $0,00 \%$ & & & 1 & $1,79 \%$ & \\
\hline -No answer & 47 & $50,00 \%$ & 0 & $0,00 \%$ & 2 & $11,76 \%$ & & & 45 & $80,36 \%$ & \\
\hline Gastrointestinal & $\mathrm{n}$ & $\%$ & $\mathrm{n}$ & $\%$ & $\mathrm{n}$ & & $\%$ & & $\mathrm{n}$ & & $\%$ \\
\hline -No answer & 8 & $8,51 \%$ & 3 & $14,29 \%$ & 2 & & $11,76 \%$ & & 3 & & $5,36 \%$ \\
\hline -No tubing & 22 & $23,40 \%$ & 15 & $71,43 \%$ & 5 & & $29,41 \%$ & & 2 & & $3,57 \%$ \\
\hline -PT, eating allowed & 6 & $6,38 \%$ & 1 & $4,76 \%$ & 5 & & $29,41 \%$ & & 0 & & $0,00 \%$ \\
\hline -PT, no eating & 4 & $4,26 \%$ & 1 & $4,76 \%$ & 2 & & $11,76 \%$ & & 1 & & $1,79 \%$ \\
\hline -multiple conditions & 54 & $57,45 \%$ & 1 & $4,76 \%$ & 3 & & $17,65 \%$ & & 50 & & $89,29 \%$ \\
\hline Cause & 19 & $20,2 \%$ & 4 & $4,3 \%$ & 8 & & & $8,5 \%$ & 7 & & $7,4 \%$ \\
\hline -Neurological & 19 & $20,2 \%$ & 16 & $17 \%$ & 3 & & & $3,2 \%$ & 0 & & $0 \%$ \\
\hline -ENT/radio-chemo & 1 & $1,1 \%$ & 0 & $0 \%$ & 1 & & & $1,1 \%$ & 0 & & $0 \%$ \\
\hline -Traumatic & 4 & $4,3 \%$ & 0 & $0 \%$ & 3 & & & $3,2 \%$ & 1 & & $1,1 \%$ \\
\hline $\begin{array}{l}\text {-Others } \\
\text {-Multiple }\end{array}$ & 50 & $53,2 \%$ & 0 & $0 \%$ & 2 & & & $2,2 \%$ & 48 & & $51,1 \%$ \\
\hline Age objective (years) & $\begin{array}{l}43,39 \\
\text { (mean) }\end{array}$ & $\begin{array}{l}13,51 \\
(\mathrm{SD})\end{array}$ & 48,01 (mean) & $\begin{array}{l}12,58 \\
(\mathrm{SD})\end{array}$ & $\begin{array}{l}49,07 \\
\text { (mean) }\end{array}$ & & & $\begin{array}{l}21,37 \\
(\mathrm{SD})\end{array}$ & $\begin{array}{l}39,67 \\
\text { (mean) }\end{array}$ & & $\begin{array}{l}9,08 \\
(\mathrm{SD})\end{array}$ \\
\hline Age subjective (years) & $\begin{array}{l}43,91 \\
\text { (mean) }\end{array}$ & $\begin{array}{l}14,81 \\
(\mathrm{SD})\end{array}$ & $\begin{array}{l}54,53 \\
\text { (mean) }\end{array}$ & $\begin{array}{l}14,31 \\
(\mathrm{SD})\end{array}$ & $\begin{array}{l}52,83 \\
\text { (mean) }\end{array}$ & & & $\begin{array}{l}18,90 \\
(\mathrm{SD})\end{array}$ & $\begin{array}{l}36,29 \\
\text { (mean) }\end{array}$ & & $\begin{array}{l}8,45 \\
(\mathrm{SD})\end{array}$ \\
\hline Gender & 84 & $89,36 \%$ & 16 & $76,19 \%$ & 14 & & & $87,5 \%$ & 54 & & $96,43 \%$ \\
\hline -Female & 6 & $6,38 \%$ & 5 & $23,81 \%$ & 1 & & & $6,25 \%$ & 1 & & $1,79 \%$ \\
\hline -Male & 0 & $0 \%$ & 0 & $0,0 \%$ & 0 & & & $0 \%$ & 0 & & $0 \%$ \\
\hline $\begin{array}{l}\text {-Divers } \\
\text {-No answer }\end{array}$ & 4 & $4,26 \%$ & 0 & $0,0 \%$ & 2 & & & $6,25 \%$ & 1 & & $1,79 \%$ \\
\hline
\end{tabular}




\section{Results}

\section{Participants' Characteristics and Descriptive Data}

Altogether we included 95 of 169 German-speaking participants who completed the entire survey. Of these completers, 21 were dysphagia patients, 17 were relatives (three of those with a medical education), and 56 were multiprofessional health care providers (physicians, speech and language therapists, and nurses) caring for patients suffering from dysphagia. One person did not answer the question and was excluded from further group-specific validation leaving 94 for further analysis. We depicted the descriptive data in Table 2.

Regular occurrence of coughing occurred in $80 \%$ of all patients $(\mathrm{FM}+\mathrm{PAT})$, with $13 \%$ of those with need for emergency care experienced at least once. Cyanosis was described by $24 \%$. Four percent reported to have needed critical care. Pneumonia was described in $34.5 \%$ with need for medical assistance or hospital admission. Loss of weight was witnessed by $51 \%$ with need for medical assistance. Of those, $14 \%$ reported to experience hospital admission. Dehydration led to medical admission in $34 \%$ of the patients. Health care providers reported about these experiences more often: $50 \%$ experienced need of medical assistance for coughing, 58\% for cyanosis, $94 \%$ for pneumonia, $87 \%$ for loss of weight, and $80 \%$ for dehydration.

Data from participants not completing the questionnaire were excluded from analysis.

\section{Main Results}

\section{Test Reliability}

Reliability analysis for the whole survey and all participants showed a Cronbach's Alpha of 0.93 and all Guttman's lambda above 0.9 .

For the subgroups, a very high Cronbach's Alpha of 0.88 for family members, 0.96 for health care providers, and 0.81 for patients was calculated. For further analysis, a Cronbach's Alpha [32] of at least 0.6 was considered useful, one of at least 0.8 shows good reliability. For all subgroups, all Guttman's lambdas were above 0.79 again showing good reliability.

\section{Test Construct Validity}

To justify primary component analysis (PCA), we could calculate a Kaiser-Meyer-Olkin (KMO) measure of sampling of 0.811 . Bartlett's test for sphericity could not be accomplished due to missing normal distribution of data and confirmed by a Levene test $(p<0.001)$. In PCA, only factors with eigenvalues of 1 or more were considered for further analysis. Components explaining less than $10 \%$ of the variance were extracted. Examinations of Kaiser's criteria and scree plots showed two factors accounting for $47.7 \%$ of the variance. After Varimax Rotation, two main factors could be identified: the first factor for "Emotion"-Items, the second for "Calgary"-Items (see Table 3).

\section{Quantitative Results of the Survey}

Results showed for all groups that participants mainly experience sadness, anxiety, and the feeling to be punished (see Table 4). We could show that family factors, especially internal (e.g., family members), external (e.g., the wider family system like friends), and instrumental (daily activities) items, have a strong interaction with dysphagia. We considered interactions to be strong for answers with more than 3 points.

Next, we conducted the group-specific comparison of Likert scale answers with exclusion of responses stating " $n o$ answer possible". These tests were corrected by Bonferroniadjusted Kruskal-Wallis tests $(p<0.0167)$. Forty-Four complete datasets were left for this analysis (10 family members, 22 health care providers, and 12 patients) which showed some significant subgroup differences:

Patients significantly experienced anger and sadness more often than health care providers and family members. Anxiety was significantly higher in family members than in the other groups, while patients reported about the feeling to be punished more often than the others.

Correlation analysis showed significant positive correlations for at least 2 of 3 anger-items interacting with punishment- and anxiety-items $(\tau>0.6, p<0.05)$. Enjoyment was negative correlated with anxiety $(\tau<-0.6, p<0.05)$ and sadness positive correlated with two of three punishmentitems. Disgust was positively correlated with most shameitems. Further minor correlations could be detected but were not significant.

\section{Qualitative Results}

The qualitative analysis revealed 7 main themes for anger, 2 for enjoyment, 4 for sadness, 3 for anxiety, 2 for disgust, and each one for punishment and shame. Anger was most diverse and there were some striking differences between the perceptions of health care providers, family members, and patients. However, all results must be considered under the selection bias especially excluding patients not capable to answer or with communication difficulties. Furthermore, our results were recorded in German language followed by the idiomatic translation after the coding process. 
Table 3 Results from 44 complete datasets without the answer "no answer possible"

\begin{tabular}{|c|c|c|c|c|c|c|c|c|}
\hline & MIN & MAX & Q1 & Modal & Q3 & mean & variance & $\mathrm{SD}$ \\
\hline Anger 1 | FM & 1 & 5 & 3 & 3 & 5 & 3.462 & 1.769 & 1.330 \\
\hline Anger $1 \mid \mathrm{HCP}$ & 1 & 5 & 3 & 4 & 5 & $3.960 *$ & 1.304 & 1.142 \\
\hline Anger 1 I PAT & 1 & 5 & 3 & 3 & 4 & $3.158^{*}$ & 1.474 & 1.214 \\
\hline Enjoyment 1। FM & 2 & 5 & 5 & 5 & 5 & 4.533 & 0.838 & 0.915 \\
\hline Enjoyment 1 । HCP & 1 & 5 & 3 & 5 & 5 & 4.085 & 1.471 & 1.213 \\
\hline Enjoyment 1 । PAT & 3 & 5 & 5 & 5 & 5 & 4.632 & 0.579 & 0.761 \\
\hline Sadness 1।FM & 1 & 4 & 1 & 2 & 3 & 2.143 & 1.209 & 1.099 \\
\hline Sadness 1 I HCP & 1 & 5 & 3 & 3 & 4 & $3.115^{*}$ & 1.241 & 1.114 \\
\hline Sadness 1 | PAT & 1 & 5 & 1 & 2 & 3 & $2.150^{*}$ & 1.818 & 1.348 \\
\hline Disgust 1।FM & 2 & 5 & 5 & 5 & 5 & 4.538 & 0.936 & 0.967 \\
\hline Disgust 1 । HCP & 2 & 5 & 5 & 5 & 5 & $4.700 *$ & 0.459 & 0.678 \\
\hline Disgust 1 | PAT & 1 & 5 & 3 & 4 & 5 & $3.950 *$ & 1.418 & 1.191 \\
\hline Anxiety 1 | FM & 1 & 3 & 1 & 1 & 2 & $1.400 * \wedge$ & 0.400 & 0.632 \\
\hline Anxiety 1 । HCP & 1 & 5 & 1 & 2 & 3 & $2.260^{\wedge}$ & 1.462 & 1.209 \\
\hline Anxiety 1 । PAT & 1 & 5 & 2 & 3 & 3 & $2.600 *$ & 1.305 & 1.142 \\
\hline Punishment 1।FM & 1 & 5 & 3 & 3 & 4 & 3.083 & 2.265 & 1.505 \\
\hline Punishment 1 I HCP & 1 & 5 & 5 & 5 & 5 & $4.711^{*}$ & 0.710 & 0.843 \\
\hline Punishment 1 I PAT & 1 & 5 & 1 & 2 & 4 & $2.550 *$ & 2,787 & $1 . .669$ \\
\hline Shame 1 IFM & 1 & 5 & 4 & 5 & 5 & 4.214 & 1,720 & 1.311 \\
\hline Shame 1 I HCP & 3 & 5 & 5 & 5 & 5 & $4.809 *$ & 0.289 & 0.537 \\
\hline Shame 1। PAT & 1 & 5 & 2 & 4 & 5 & $3.450 *$ & 2.471 & 1,572 \\
\hline Anger $2 \mid \mathrm{FM}$ & 1 & 5 & 3 & 4 & 5 & $3.500 *$ & 2.115 & 1.454 \\
\hline Anger 2 I HCP & 1 & 5 & 3 & 4 & 5 & $3.756^{\wedge}$ & 1.416 & 1.190 \\
\hline Anger 2 I PAT & 1 & 5 & 1 & 3 & 4 & $2.800 * \wedge$ & 2.274 & 1.508 \\
\hline Enjoyment 2 I FM & 3 & 5 & 5 & 5 & 5 & 4,714 & 0.527 & 0.726 \\
\hline Enjoyment 2 । HCP & 2 & 5 & 5 & 5 & 5 & $4.837 *$ & 0.330 & 0.574 \\
\hline Enjoyment 2 । PAT & 2 & 5 & 5 & 5 & 5 & $4.600 *$ & 0.779 & 0.883 \\
\hline Sadness 2 | FM & 1 & 4 & 1 & 2 & 3 & 2.200 & 1.457 & 1.207 \\
\hline Sadness 2 | HCP & 1 & 5 & 2 & 3 & 4 & 2.978 & 1.400 & 1.183 \\
\hline Sadness 2 I PAT & 1 & 5 & 1 & 2 & 2 & 2.100 & 1.884 & 1.373 \\
\hline Disgust 2 | FM & 1 & 5 & 3 & 3 & 5 & 3.500 & 1.962 & 1.401 \\
\hline Disgust 2 | HCP & 1 & 5 & 3 & 5 & 5 & 4.023 & 1.418 & 1.191 \\
\hline Disgust 2 | PAT & 1 & 5 & 2 & 4 & 5 & 3.400 & 2.253 & 1.501 \\
\hline Anxiety 2 । FM & 1 & 4 & 1 & 2 & 3 & $2.067 *$ & 1.210 & 1.100 \\
\hline Anxiety 2 । HCP & 1 & 5 & 2 & 3 & 4 & $3.196 *$ & 1.716 & 1.310 \\
\hline Anxiety 2 I PAT & 1 & 5 & 2 & 3 & 4 & 2.850 & 2.345 & 1.531 \\
\hline Punishment 2 | FM & 1 & 5 & 4 & 4 & 5 & 3.923 & 1.577 & 1.256 \\
\hline Punishment 2 । HCP & 1 & 5 & 3 & 5 & 5 & $4.295^{*}$ & 1.190 & 1.091 \\
\hline Punishment 2 | PAT & 1 & 5 & 2 & 3 & 5 & $3.200 *$ & 2.379 & 1.542 \\
\hline Shame 2 | FM & 1 & 5 & 3 & 5 & 5 & 4.214 & 1.566 & 1.251 \\
\hline Shame 2 । HCP & 1 & 5 & 4 & 4 & 5 & 4.091 & 1.247 & 1.117 \\
\hline Shame 2 I PAT & 1 & 5 & 3 & 3 & 5 & 3.550 & 1.629 & 1.276 \\
\hline Anger 3 | FM & 1 & 5 & 2 & 3 & 5 & 3.267 & 2.638 & 1.624 \\
\hline Anger 3 | HCP & 1 & 5 & 3 & 4 & 5 & $3.644^{*}$ & 1.643 & 1.282 \\
\hline Anger 3 I PAT & 1 & 5 & 1 & 3 & 3 & $2.600 *$ & 1.937 & 1.392 \\
\hline Enjoyment 3 I FM & 3 & 5 & 5 & 5 & 5 & 4.714 & 0.374 & 0.611 \\
\hline Enjoyment 3 । HCP & 2 & 5 & 5 & 5 & 5 & 4.867 & 0.255 & 0.505 \\
\hline Enjoyment 3 । PAT & 2 & 5 & 5 & 5 & 5 & 4.750 & 0.513 & 0.716 \\
\hline Sadness 3 | FM & 1 & 5 & 2 & 3 & 4 & 2.733 & 1.638 & 1.280 \\
\hline Sadness 3 | HCP & 1 & 5 & 3 & 4 & 5 & $3.851 *$ & 1.564 & 1.251 \\
\hline Sadness 3 | PAT & 1 & 5 & 2 & 3 & 3 & $2.700 *$ & 1.800 & 1.342 \\
\hline
\end{tabular}


Table 3 (continued)

\begin{tabular}{|c|c|c|c|c|c|c|c|c|}
\hline & MIN & MAX & Q1 & Modal & Q3 & mean & variance & SD \\
\hline Disgust 3 | FM & 2 & 5 & 4 & 5 & 5 & 4.400 & 0.971 & 0.986 \\
\hline Disgust 3 | HCP & 2 & 5 & 5 & 5 & 5 & 4.696 & 0.483 & 0.695 \\
\hline Disgust 3 | PAT & 1 & 5 & 3 & 4 & 5 & 4.000 & 1.263 & 1.124 \\
\hline Anxiety 3 I FM & 1 & 5 & 2 & 2 & 4 & 2.667 & 2.095 & 1.447 \\
\hline Anxiety 3 । HCP & 1 & 5 & 3 & 4 & 5 & 3.630 & 1.927 & 1.388 \\
\hline Anxiety 3 । PAT & 1 & 5 & 2 & 3 & 3 & 2.850 & 1.924 & 1.387 \\
\hline Punishment 3 | FM & 1 & 5 & 1 & 3 & 5 & 3.000 & 2.857 & 1.690 \\
\hline Punishment 3 । HCP & 1 & 5 & 2 & 4 & 5 & $3.556 *$ & 2.298 & 1.516 \\
\hline Punishment 3 | PAT & 1 & 5 & 1 & 2 & 4 & $2.650 *$ & 2.345 & 1.531 \\
\hline Shame 3 | FM & 1 & 5 & 4 & 5 & 5 & 4.200 & 1.743 & 1.320 \\
\hline Shame 3 । HCP & 1 & 5 & 4 & 5 & 5 & 4.244 & 0.916 & 0.957 \\
\hline Shame 3 I PAT & 1 & 5 & 2 & 3 & 5 & 3.400 & 2.042 & 1.429 \\
\hline Construct 1 I FM & 1 & 5 & 2 & 5 & 5 & 3.667 & 3.095 & 1.759 \\
\hline Construct 1 । HCP & 1 & 5 & 3 & 5 & 5 & 3.977 & 1.833 & 1.354 \\
\hline Construct 1। PAT & 1 & 5 & 4 & 5 & 5 & 4.333 & 1.515 & 1.231 \\
\hline External 1 | FM & 1 & 5 & 1 & 3 & 3 & 2.500 & 1.867 & 1.366 \\
\hline External 1 । HCP & 1 & 5 & 2 & 2 & 3 & 2.373 & 0.958 & 0.979 \\
\hline External 1 I PAT & 1 & 5 & 1 & 3 & 3 & 2.421 & 1.591 & 1.261 \\
\hline Internal 1 | FM & 1 & 5 & 1 & 2 & 3 & 2.500 & 2.400 & 1.549 \\
\hline Internal 1 । HCP & 1 & 5 & 2 & 3 & 3 & 2.647 & 1.033 & 1.016 \\
\hline Internal 1 | PAT & 1 & 5 & 3 & 3 & 4 & 3.105 & 1.433 & 1.197 \\
\hline Instrumental 1 | FM & 1 & 4 & 1 & 2 & 2 & 1.875 & 0.917 & 0.957 \\
\hline Instrumental 1 । HCP & 1 & 5 & 1 & 2 & 3 & 2.098 & 0.970 & 0.985 \\
\hline Instrumental 1 । PAT & 1 & 5 & 1 & 2 & 3 & 2.263 & 1.205 & 1.098 \\
\hline Expressive 1 । FM & 1 & 5 & 1 & 2 & 5 & 2.750 & 3.000 & 1.732 \\
\hline Expressive 1 I HCP & 1 & 5 & 3 & 3 & 4 & 3.294 & 1.452 & 1.205 \\
\hline Expressive 1। PAT & 1 & 5 & 3 & 4 & 5 & 3.889 & 1.634 & 1.278 \\
\hline Developmental 1।FM & 1 & 5 & 1 & 3 & 4 & 2.667 & 2.381 & 1.543 \\
\hline Developmental 1 । HCP & 1 & 5 & 2 & 3 & 4 & 3.000 & 1.545 & 1.243 \\
\hline Developmental 1 । PAT & 1 & 5 & 3 & 4 & 5 & 3.471 & 2.015 & 1.419 \\
\hline Construct 2 |FM & 1 & 3 & 1 & 1 & 1 & 1.235 & 0.316 & 0.562 \\
\hline Construct 2 । HCP & 1 & 5 & 1 & 1 & 2 & 1.558 & 0.761 & 0.873 \\
\hline Construct 2 I PAT & 1 & 5 & 1 & 1 & 3 & 1.895 & 1.433 & 1.197 \\
\hline External 2 | FM & 1 & 4 & 1 & 1 & 2 & 1.529 & 0.765 & 0.874 \\
\hline External 2 । HCP & 1 & 3 & 1 & 1 & 2 & 1.636 & 0.606 & 0.778 \\
\hline External 2 | PAT & 1 & 3 & 1 & 1 & 2 & 1.684 & 0.673 & 0.820 \\
\hline Internal $2 \mid \mathrm{FM}$ & 1 & 4 & 1 & 1 & 2 & 1.529 & 0.890 & 0.943 \\
\hline Internal 2 । HCP & 1 & 5 & 1 & 2 & 2 & 1.818 & 0.892 & 0.945 \\
\hline Internal 2 | PAT & 1 & 4 & 1 & 2 & 3 & 2.211 & 0.953 & 0.976 \\
\hline Instrumental 2 | FM & 1 & 2 & 1 & 1 & 1 & 1.176 & 0.154 & 0.393 \\
\hline Instrumental 2 | HCP & 1 & 3 & 1 & 1 & 1 & 1.236 & 0.258 & 0.508 \\
\hline Instrumental 2 | PAT & 1 & 3 & 1 & 1 & 2 & 1.444 & 0.379 & 0.616 \\
\hline Expressive 2 | FM & 1 & 3 & 1 & 1 & 1 & 1.250 & 0.467 & 0.683 \\
\hline Expressive 2 | HCP & 1 & 5 & 1 & 2 & 3 & 1.873 & 0.891 & 0.944 \\
\hline Expressive 2 | PAT & 1 & 4 & 1 & 2 & 3 & 2.105 & 1.099 & 1.049 \\
\hline Developmental 2 | FM & 1 & 5 & 1 & 2 & 2 & 2.063 & 1.396 & 1.181 \\
\hline Developmental 2 I HCP & 1 & 5 & 2 & 3 & 4 & 2.691 & 1.440 & 1.200 \\
\hline Developmental 2 | PAT & 1 & 5 & 2 & 3 & 4 & 2.842 & 1.140 & 1.068 \\
\hline Construct 3 | FM & 1 & 5 & 3 & 4 & 5 & 3.400 & 1.971 & 1.404 \\
\hline Construct 3 । HCP & 1 & 5 & 2 & 3 & 4 & 2.735 & 1.866 & 1.366 \\
\hline Construct 3 I PAT & 1 & 5 & 3 & 5 & 5 & 4.056 & 1.350 & 1.162 \\
\hline
\end{tabular}


Table 3 (continued)

\begin{tabular}{lllllllll}
\hline & MIN & MAX & Q1 & Modal & Q3 & mean & variance & SD \\
\hline External 3 | FM & 1 & 5 & 1 & 2 & 3 & 2.313 & 1.963 & 1.401 \\
External 3 | HCP & 1 & 5 & 1 & 2 & 3 & 2.308 & 1.198 & 1.094 \\
External 3 | PAT & 1 & 5 & 2 & 3 & 4 & 2.842 & 1.696 & 1,302 \\
internal 3 I FM & 1 & 5 & 1 & 2 & 2 & 1.813 & 1.363 & 1.167 \\
Internal 3 | HCP & 1 & 5 & 1 & 2 & 3 & 2.057 & 1.093 & 1.045 \\
Internal 3 | PAT & 1 & 4 & 2 & 2 & 4 & 2.474 & 1.263 & 1.124 \\
Instrumental 3 | FM & 1 & 4 & 1 & 1 & 2 & 1.600 & 0.829 & 0.910 \\
Instrumental 3 | HCP & 1 & 5 & 1 & 1 & 2 & 1.778 & 1,082 & 1.040 \\
Instrumental 3 | PAT & 1 & 4 & 1 & 2 & 3 & 2.000 & 0.941 & 0.970 \\
Expressive 3 | FM & 1 & 5 & 2 & 2 & 4 & 2.667 & 2.095 & 1.447 \\
Expressive 3 | HCP & 1 & 5 & 3 & 3 & 4 & 3,255 & 1.474 & 1.214 \\
Expressive 3 | PAT & 1 & 5 & 3 & 4 & 5 & 3.611 & 1.781 & 1.335 \\
Developmental 3 | FM & 1 & 5 & 2 & 2 & 4 & 2.667 & 1.952 & 1.397 \\
Developmental 3 | HCP & 1 & 5 & 2 & 3 & 4 & 2.824 & 1.188 & 1.090 \\
Developmental 3 | PAT & 1 & 5 & 3 & 4 & 5 & 3.667 & 2.353 & 1.534 \\
\hline
\end{tabular}

Mean values show the grade to disagree on the question how emotions or family aspects play a role in dysphagia with no agree (5) to full agreement (1) on the Likert scale. Groups were family members (FM), Health care providers (HCP), and Patients (PAT). Significances $(p<0.0167$, Bonferroni-corrected) are marked with $(*)$ or $\left({ }^{\wedge}\right)$ and refer to the same items

\section{Anger}

Concerning anger, we analyzed 53 free text inputs. We identified the following themes: On the side of patient there were some without any feeling of anger (Theme 1: Patients feel no anger) and some with severe frustration mainly about their own capabilities (Theme 2: Patients are frustrated about dysphagia and dependency). Patients did not mention anger about other persons: "I am angry, when I fail", "I am angry about myself when I swallow the wrong way if I was not cautious" and "I am angry if I need special assistance" were some examples.

Health care providers confirmed this theme with statements like "patients are angry if they cannot be served their favorite meal" but repetitively projected anger towards their profession (Theme 3: Patients feel anger for their therapists): "They do not perceive their problems and get angry about me", "Some are angry if I limit their meals", "They feel angry about their body, which is not functioning anymore and when they are not allowed to eat as they like". For themselves, health care providers felt angry when others ignore safety advices, for insufficient medical education in dysphagiology and resulting overconfidence of others (Theme 4: Health care Providers are angry about insufficient medical education and overconfidence of other professionals): "I am angry about nurses who feed the patient without caring for swallowing disorders", "I am angry about the charlatans who think they can manage dysphagia", "I am angry about nurses not spending enough time" and "I am angry, if other speech and language therapist could conduct a FEES, but do not do it, stick to clinical assessment and then the patient gets worse" were common entries. As an additional theme, health care providers reported about incompliance by patients and relatives to their advice (Theme 5: Health care providers are angry for inadherence to dysphagia therapy plans): "They eat in secrecy", "Relatives give them to eat endangering them").

Family members reported about anger for fateful events leading to dysphagia (Theme 6: family members feel anger for fateful dysphagia) and for reactions of the environment (Theme 7: family members feel anger for the reaction of others): "I am angry when restaurant employees refuse to mash the food", and "I am angry for my child being affected so hard" and "Why is this MY daughter's fate?" were examples. On the other hand, there also was anger concerning patients: "He is all the time grumbling about his espresso he cannot drink. That's annoying".

\section{Enjoyment}

We analyzed 54 entries for "enjoyment" an derived Themes 8 and 9 from it: About half the participants of all subgroups stated that there is no enjoyment (Theme 8), while the others reported about enjoyment for any success in dysphagia therapy (Theme 9): "If friends say, that they are not annoyed if I eat", "If I CAN swallow something without pain", "When there is some success", "When I can allow them to eat again" were some of the examples. 
Table 4 Factor loading for the two dimensions after VARIMAX Rotation

\begin{tabular}{|c|c|c|}
\hline Item & D1 & D2 \\
\hline Anger 1 & 0.337 & 0.005 \\
\hline Enjoyment 1 & 0.028 & $\mathbf{0 . 0 3 0}$ \\
\hline Sadness 1 & 0.293 & 0.000 \\
\hline Disgust 1 & 0.273 & 0.000 \\
\hline Anxiety 1 & 0.197 & 0.021 \\
\hline Punishment 1 & 0.525 & 0.005 \\
\hline Shame 1 & 0.532 & 0.001 \\
\hline Anger 2 & 0.632 & 0.048 \\
\hline Enjoyment 2 & 0.410 & 0.017 \\
\hline Sadness 2 & 0.522 & 0.012 \\
\hline Disgust 2 & 0.739 & 0.006 \\
\hline Anxiety 2 & 0.520 & 0.012 \\
\hline Punishment 2 & 0.723 & 0.020 \\
\hline Shame 2 & 0.662 & 0.025 \\
\hline Anger 3 & 0.593 & 0.025 \\
\hline Enjoyment 3 & 0.404 & 0.050 \\
\hline Sadness 3 & 0.646 & 0.043 \\
\hline Disgust 3 & 0.729 & 0.011 \\
\hline Anxiety 3 & 0.730 & 0.007 \\
\hline Punishment 3 & 0.578 & 0.003 \\
\hline Shame 3 & 0.580 & 0.003 \\
\hline Context 1 & 0.024 & 0.284 \\
\hline External 1 & 0.069 & 0.343 \\
\hline Internal 1 & 0.034 & 0.517 \\
\hline Instrumental 1 & 0.069 & 0.417 \\
\hline Expressive 1 & 0.070 & 0.415 \\
\hline Developmental 1 & 0.022 & 0.412 \\
\hline Context 2 & 0.005 & 0.322 \\
\hline External 2 & 0.008 & 0.339 \\
\hline Internal 2 & 0.004 & 0.401 \\
\hline Instrumental 2 & 0.023 & 0.182 \\
\hline Expressive 2 & 0.006 & 0.367 \\
\hline Developmental 2 & 0.020 & 0.339 \\
\hline Context 3 & 0.008 & 0.355 \\
\hline External 3 & 0.009 & 0.430 \\
\hline Internal 3 & 0.002 & 0.490 \\
\hline Instrumental 3 & 0.008 & 0.438 \\
\hline Expressive 3 & 0.025 & 0.373 \\
\hline Developmental 3 & 0.011 & 0.473 \\
\hline
\end{tabular}

Items in bold are those with highest factor loading for an emotion or family factor. Dimension 1 mainly loads on emotions, dimension 2 on Calgary factors. One exception is enjoyment 1 loading on family factors

\section{Sadness}

Fifty-four participants made a statement on sadness. In all groups, the following themes occurred regularly: We detected frustration (Theme 10) in the following phrases: "I am sad, if long lasting therapy fails", "I get frustrated and sad when relatives do not accept the medical condition", "I am sad when I see others eating and I am not able to", "I am frustrated when I want to have a meal with somebody. Unfortunately, it is not possible. When I am not concentrated, I aspirate". Second main themes were the loss of taste (Theme 11) and social isolation (Theme 12). Additionally, compassion (Theme 13) was mentioned for patients but also from the side of passions towards their family members: "I think my family members are anxious about my condition."

\section{Anxiety}

Fifty-five participants commented on anxiety. In all groups, the concern that therapies fail (Theme 14) and the fear to die by choking (Theme 15) plays a major role: "Cruelly gasping", "Anxiety? What a question! Naturally! I fear my mother dies by choking", "I am concerned the ambulance will not make in time", "I witness phagophobia regularly", "they fear to die" were common entries. On side of family members and health care providers, the fear to make a mistake (Theme 16) was also common: "When I was younger, I was afraid to allow too complex meals", "I regularly think about my decisions about the food I am allowing" while patients also mentioned this fear: "I fear to make a mistake in choice of my meal".

\section{Disgust}

Only 48 persons commented on disgust and most stated that they are not experiencing it: "No there is no disgust. Even when my husband vomited blood in the end". On the other side, some participants noticed disgust for the food or secretions (Theme 17) by others or the disgust for the monotonous strained foods (Theme 18). Patient confirmed these two themes: "Meals are disgusting at all", "I am disgusted if I vomit or lose control over the food in my mouth".

\section{Punishment}

The feeling to be punished with dysphagia showed to be irritating for most participants of whom 42 answered. Some, mainly patients agreed that illnesses mainly provoke the question "Why me?": "I was a butcher. Now a cannot eat a steak anymore. This is a punishment!", "Yes. I was very young, and I have to live with it for many years. Why me?". One participant reversed it in a resilient way: "I am religious. God guides me. I learned a lot from dysphagia" (Theme 19: Dysphagia induces resilience). 


\section{Shame}

Shame was confirmed by most of the 42 participants answering. Shameful eating in public spaces (Theme 20) was the most common answer: "If I provoke attention in a concert or restaurant. That is ashaming", "Shameful eating is one of the big themes in dysphagia therapy", "They feel ashamed not to eat a normal way", "I feel ashamed when I am dirtying myself", "I am ashamed when I slobber", "In a restaurant I would have to use my swallowing strategies. But nobody would understand my lying backwards on the floor".

\section{Discussion}

\section{Key Results}

To our knowledge, the JDEFA is the first questionnaire addressing emotion and family aspects in patients, family members, and professionals experiencing dysphagia. Our findings demonstrate after face and content validity in the development-phase acceptable construct validity and reliability. With regard to a Cronbach's alpha above 0.9 [32] and the high premature drop-out of 70 participants (loss of follow-up bias), shortening of the questionnaire is indicated.

With respect to concentration deficits [33] and fatigue [34] especially for stroke patients suffering from dysphagia (and aphasia), a shortened questionnaire comprising the factors with best loadings (bold items in Table 4) may be more useful after intensive reevaluation of the tool itself and a possible reliability-validity dilemma in other populations.

Further statistical concerns derive from the two-dimensional factor loading. With seven feelings and emotions and six Calgary elements, more dimensions were expected. However, distinction of emotions by others, their interaction with individual cognition is difficult, even in healthy persons [35]. Clues for this explanation may be the high intercorrelations of emotions and the enjoyment- 1 item factor loading on family factors instead of emotions: While most emotions are primarily "negative", enjoyment is "positive"-like most family items. Nevertheless, the distinct factor loading on two dimensions (with one exception) strengthens validity of the survey with good differentiation of emotions and family factors.

On the side of quantitative analysis, we could demonstrate that patients experience more often anger and sadness as well as the feeling to be punished than others leading to the question if these different results are due to a selection bias or due to reduced empathic accuracy in the triad of patient-family-therapist relationships [36]. Whereas anxiety is well described [11] for dysphagia, other emotions and family elements are condensed to quality of life [17]. Thus, parts of our study confirm prior findings (in other settings) strengthening content validity.

To our knowledge, there is no study in dysphagia addressing empathic accuracy yet. We did not measure that with this survey but validated an assessment tool in three groups able to be used for in future investigations. Our qualitative data indicate that empathic accuracy may be impaired in several cases: while therapists mentioned multiple times that they feel to be made responsible for failings in therapies, none of the patient mentioned this. However, in other cases qualitative data show that many dysphagia problems like shame in restaurants, anxiety for aspiration, and choking are obvious and known.

We know that empathic accuracy in healthy adults is low, only about $22 \%$ of all reactions are correct empathic readings in another person [25]. Regarding dysphagia, we do not know about empathic accuracy in dysphagia patients coming from vastly different populations (neurological, oncological, pediatric, ...). It is questionable if accuracy may be higher or lower under concern of stress, aphasia, apraxia, cerebral and cognitive deficits after stroke, loss of paraverbal communication after tracheostomy, or loss of facial expression in facial palsy or after surgical therapies.

Concerning family functionality, there also are several studies showing influences and dependencies reviewed in [15], but to our knowledge no setting put it into context with the CFAM/CFIM. However, the need for counseling training in speech and language therapists is well known on the side of therapists giving support to patients [37,38]. On the other side, we could not find literature about well-being and mental health of the therapists themselves, especially on our finding of high stress levels for making mistakes in food recommendations - possibly resulting in aspiration, choking, and death of patients. In worst case, this may lead to the death of a patient and a second victim effect of the therapist [39], phagophobia [40], or "overcautious" physician/therapist anxiety triggering too early percutaneous gastral tubing, tracheostomy, and withdrawal of a per oral diet. However, dramatic experiences as presented in the demographics section show that therapists regularly experience these lifethreatening conditions.

\section{Limitations}

There are following limitations to our work as a first approach:

First, the selection and gender bias, a classical error for all surveys, may play a significant role. Addressed persons were only German Speaking participants, predominantly women in groups FM and HCP with online access and who were reached by our networks. Demographic data about tubing and tracheotomy show that family members and patient 
are affected mild to moderate. Data for persons with severe affection were not obtained. However, our broad approach and dissemination may lower the bias without ruling it out and leaving space for further investigations and validations in distinct populations. Additionally, our work concentrated on the validation of a testing instrument, not to demonstrate the psycho-emotional situation in German-speaking countries concerning dysphagia.

Second, the decay of methods bias may play a role in answering all items. With a reduction to a short version, this could be addressed under recognition of limited capacities in some patients.

Third, we decided to include a "no answer possible" in the Likert scale. Although we deleted items with this possible answer for further analysis, this "non-ordinal" element may disturb statistical analysis. However, discussions with therapists in the development phase clearly indicated for the possibility to leave this option of indeterminacy due to content validity.

Forth, we only assessed five basic emotions [41] and 2 feelings, leaving hundreds of other feelings (envy, proudness, surprise, ...) and intensity gradations of emotions [20] apart. Those may be addressed by further investigations.

Fifth, study sample size was low, with need of reevaluation in larger populations. For the purpose of statistical validation, we accepted the participant count [32].

Sixth, we did not assess criterion validity as an integral part of validity testing. While face and content validity could be reached in the development phase and were confirmed by our results, criterion validity and correlation to established psychological and dysphagia scores have not been obtained.

Thus, the next step for validation and hypothesis generation may comprise a multidimensional test battery including classical scores for dysphagia assessment like the penetration-aspiration scale [42], Bogenhausen Scores [43], the EAT-10 [19], as well as emotion assessments like the Hospital Anxiety and Depressions Scale (HADS) [44], life quality measurements [45], family assessment scores, screening scores for mental health of health care workers [46], and second victim effects [47]. However, in this very first approach, intended for construct validation and generation of new hypotheses a complete test battery for multidimensional assessment of dysphagia including subjective and objective criteria was not implemented but gives important information on future projects like "triangular" testing of emotion perception and trilateral emotional accuracy between family members, patients, and care givers.

\section{Conclusion}

As a conclusion, the main hypothesis on the novel assessment method was confirmed: Construct validity and reliability of the assessment tool could be demonstrated, and bladditional content validity shown by quantitative and qualitative data deriving from the prototypical data in a cross-sectional national survey.

Further qualitative and quantitative data gave more insight into the development of a multidimensional dysphagia assessment and indicate on the demand for medicopsychological education of dysphagia therapists and evoke the need for future work, especially on criterion validity and intercorrelation with psychological and dysphagiologic scoring systems focusing on the three subgroups.

Acknowledgements We thank Prof. Andreas Moeltner for statistical and Dr. Volker Busch for psychological advice. Additionally, we thank all members of the "Dysphagie Netzwerk Suedwest e.V." for help in the development of the survey. We also thank Sonja Schick and Gary Adkins for native speakers' support.

Funding The study was funded by the Erika-and-Werner-Messmer Foundation, Radolfzell, Germany.

\section{References}

1. Béjot $Y$, et al. Epidemiology of stroke in Europe and trends for the 21st century. Presse Med. 2016;45(12 Pt 2):e391-8.

2. Martino R, et al. Dysphagia after stroke: incidence, diagnosis, and pulmonary complications. Stroke. 2005;36(12):2756-63.

3. Roy N, et al. Dysphagia in the elderly: preliminary evidence of prevalence, risk factors, and socioemotional effects. Ann Otol Rhinol Laryngol. 2007;116(11):858-65.

4. Pezdirec M, Strojan P, Boltezar IH. Swallowing disorders after treatment for head and neck cancer. Radiol Oncol. 2019;53(2):225-30.

5. Greco E, et al. Dysphagia treatment for patients with head and neck cancer undergoing radiation therapy: a meta-analysis review. Int J Radiat Oncol Biol Phys. 2018;101(2):421-44.

6. Vansant MB, Kunduk M, McWhorter AJ. A review of postsurgical dysphagia in nonmalignant disease. Curr Opin Otolaryngol Head Neck Surg. 2016;24(6):477-82.

7. Zuercher P, et al. Dysphagia in the intensive care unit: epidemiology, mechanisms, and clinical management. Crit Care. 2019;23(1):103.

8. Duffy KL. Dysphagia in children. Curr Probl Pediatr Adolesc Health Care. 2018;48(3):71-3.

9. Patel DA, et al. Economic and survival burden of dysphagia among inpatients in the United States. Dis Esophagus. 2018;31(1):1-7.

10. Ekberg $\mathrm{O}$, et al. Social and psychological burden of dysphagia: its impact on diagnosis and treatment. Dysphagia. 2002;17(2):139-46.

11. Nguyen NP, et al. Impact of dysphagia on quality of life after treatment of head-and-neck cancer. Int J Radiat Oncol Biol Phys. 2005;61(3):772-8. 
12. Nund RL, et al. Survivors' experiences of dysphagia-related services following head and neck cancer: implications for clinical practice. Int J Lang Commun Disord. 2014;49(3):354-63.

13. Eltringham SA, et al. Experiences of dysphagia after stroke: an interview study of stroke survivors and their informal caregivers. Geriatrics (Basel). 2019;4(4):67.

14. Lisiecka D, Kelly H, Jackson J. How do people with motor neurone disease experience dysphagia? A qualitative investigation of personal experiences. Disabil Rehabil. 2019;43(4):479-88.

15. Namasivayam-MacDonald AM, Shune SE. The burden of dysphagia on family caregivers of the elderly: a systematic review. Geriatrics (Basel). 2018;3(2):30.

16. Shune SE, Namasivayam-MacDonald AM. Swallowing impairments increase emotional burden in spousal caregivers of older adults. J Appl Gerontol. 2020;39(2):172-80.

17. Chen SC, et al. Swallowing ability and its impact on dysphagiaspecific health-related QOL in oral cavity cancer patients posttreatment. Eur J Oncol Nurs. 2018;36:89-94.

18. Yi YG, et al. Dysphagia-related quality of life in adults with cerebral palsy on full oral diet without enteral nutrition. Dysphagia. 2019;34(2):201-9.

19. Belafsky PC, et al. Validity and reliability of the eating assessment tool (EAT-10). Ann Otol Rhinol Laryngol. 2008;117(12):919-24.

20. Ekman, P.E., Eve, The Atlas of Emotions Project Website 2014.

21. de Vere AJ, Kuczaj SA 2nd. Where are we in the study of animal emotions? Wiley Interdiscip Rev Cogn Sci. 2016;7(5):354-62.

22. Tybur JM, Lieberman D, Griskevicius V. Microbes, mating, and morality: individual differences in three functional domains of disgust. J Pers Soc Psychol. 2009;97(1):103-22.

23. Nummenmaa L, et al. Maps of subjective feelings. Proc Natl Acad Sci USA. 2018;115(37):9198-203.

24. Cabanac M. What is emotion? Behav Proc. 2002;60(2):69-83.

25. Ickes WT. The observational method: studying the interaction of minds and bodies. Handbook Personal Relationships. 1988;1:79-96.

26. William I. Measuring mind reading everydays. Mind Reading. 2003;1:51-75.

27. Larson EB, Yao X. Clinical empathy as emotional labor in the patient-physician relationship. JAMA. 2005;293(9):1100-6.

28. Kim SS, Kaplowitz S, Johnston MV. The effects of physician empathy on patient satisfaction and compliance. Eval Health Prof. 2004;27(3):237-51.

29. Zinn W. The empathic physician. Arch Intern Med. 1993;153(3):306-12.

30. Leahey M, Wright LM. Application of the calgary family assessment and intervention models: reflections on the reciprocity between the personal and the professional. J Fam Nurs. 2016;22(4):450-9.

31. Bradley EH, Curry LA, Devers KJ. Qualitative data analysis for health services research: developing taxonomy, themes, and theory. Health Serv Res. 2007;42(4):1758-72.

32. Bujang MA, Omar ED, Baharum NA. A review on sample size determination for Cronbach's alpha test: a simple guide for researchers. Malays J Med Sci. 2018;25(6):85-99.
33. Povroznik JM, et al. Executive (dys)function after stroke: special considerations for behavioral pharmacology. Behav Pharmacol. 2018;29(7):638-53.

34. Delva MY, Delva II, Lytvynenko NV. Post-stroke fatigue and its dimensions over the second half year after stroke. Wiad Lek. 2018;71(2):314-7.

35. Okon-Singer $\mathrm{H}$, et al. The neurobiology of emotion-cognition interactions: fundamental questions and strategies for future research. Front Hum Neurosci. 2015;9:58.

36. Sened $\mathrm{H}$, et al. Empathic accuracy and relationship satisfaction: a meta-analytic review. J Fam Psychol. 2017;31(6):742-52.

37. Sekhon JK, et al. Counselling training for speech-language therapists working with people affected by post-stroke aphasia: a systematic review. Int J Lang Commun Disord. 2019;54(3):321-46.

38. Northcott S, et al. How do speech-and-language therapists address the psychosocial well-being of people with aphasia? Results of a UK online survey. Int J Lang Commun Disord. 2017;52(3):356-73.

39. Wu AW. Medical error: the second victim. The doctor who makes the mistake needs help too. BMJ. 2000;320(7237):726-7.

40. Baijens LW, Koetsenruijter K, Pilz W. Diagnosis and treatment of phagophobia: a review. Dysphagia. 2013;28(2):260-70.

41. Ekman P. What Scientists Who Study Emotion Agree About. Perspect Psychol Sci. 2016;11(1):31-4.

42. Colodny N. Interjudge and intrajudge reliabilities in fiberoptic endoscopic evaluation of swallowing (fees) using the penetration-aspiration scale: a replication study. Dysphagia. 2002;17(4):308-15.

43. Bartolome G, Prosiegel M, Yassouridis A. Long-term functional outcome in patients with neurogenic dysphagia. NeuroRehabilitation. 1997;9(3): 195-204.

44. Maher EJ, et al. The use of the Hospital Anxiety and Depression Scale (HADS) and the EORTC QLQ-C30 questionnaires to screen for treatable unmet needs in patients attending routinely for radiotherapy. Cancer Treat Rev. 1996;22 Suppl A:123-9.

45. Donaldson $\mathrm{C}$, et al. QALYS and long-term care for elderly people in the UK: scales for assessment of quality of life. Age Ageing. 1988;17(6):379-87.

46. Regehr C, LeBlanc VR. PTSD, acute stress, performance and decision-making in emergency service workers. J Am Acad Psychiatry Law. 2017;45(2):184-92.

47. Burlison JD, et al. The second victim experience and support tool: validation of an organizational resource for assessing second victim effects and the quality of support resources. J Patient Saf. 2017;13(2):93-102.

Publisher's Note Springer Nature remains neutral with regard to jurisdictional claims in published maps and institutional affiliations. 